\title{
BIBECHANA
}

A Multidisciplinary Journal of Science, Technology and Mathematics ISSN 2091-0762 (Print), 2382-5340 (Online)

Journal homepage: http://nepjol.info/index.php/BIBECHANA

Publisher: Research Council of Science and Technology, Biratnagar, Nepal

\section{Traction and drawbar performance characteristics of power tiller attached cage wheel}

\author{
Piyush Pradhan $^{1 *}$, Ajay Verma ${ }^{2}$, Rajesh Naik ${ }^{3}$, Prabhat Guru ${ }^{4}$ \\ Department of Farm Machinery and Power Engineering \\ SVCAET \& RS Faculty of Agricultural Engineering IGKV Raipur-492012 Chhattisgarh, India \\ "E-mail: piyushpradhan202@gmail.com \\ Article history: Received 28 July, 2015; Accepted 11 August, 2015 \\ DOI: http://dx.doi.org/10.3126/bibechana.v13i0.13351
}

\section{Abstract}

The study was carried out in the research farm of Indira Gandhi Agricultural University Raipur Chhattisgarh in June 2014. To evaluate drawbar and tractive power of $4.85 \mathrm{~kW}$ of power tiller cultivator attached with two different types of cage wheel of half width $\left(\mathrm{C}_{1}\right)$ and angle type wheels $\left(\mathrm{C}_{2}\right)$ for a small power tiller operated in clay soil of wet land and flood condition. It was found that the maximum draft values of $\mathrm{C}_{1}$ and $\mathrm{C}_{2}$ were $1192 \mathrm{~N}$ and $1039 \mathrm{~N}$ in flood condition and $1318 \mathrm{~N}$ and $1225 \mathrm{~N}$ in wet condition. The results showed that maximum tractive efficiency was for cage wheel $C_{1}$ and $C_{2}$ values were $72.91 \%$ and $69.86 \%$ in puddle soil. The maximum field capacity was $0.084 \mathrm{ha} / \mathrm{h}$ for cage wheel $\mathrm{C}_{2}$ in puddle soil.

CRCOST: All rights reserved.

Keywords: Draft; Tractive efficiency; Field capacity; Fuel consumption; Wheel slippage; Cage wheel.

\section{Introduction}

Power tiller is walking tractor mostly used for rotary cultivation in puddle soil. Cage wheel have proved one of the important traction devices for wetland cultivation. Physical conditions of the soil in poorly drained paddy fields were also defined to distinguish it from the general wetlands. The efficiency with which a Power tiller converts energy into pull is extremely poor when operating on wet soil. The top layer of wet soil has low shear strength so that sufficient thrust cannot be developed [1]. Due to the slippage, stickiness and sinkage limit in driving wheel affect the available pull and forward speed of a power tiller. In such situations the middle layer of the soil bears the traffic load of agricultural machinery. Studies conducted to test a $7.46 \mathrm{~kW}$ power tiller for drawbar pull, fuel consumption and wheel slip by Alvi and Pandya [2], have revealed low drawbar pull and power and high specific fuel consumption. The testing of 
a $4.10 \mathrm{~kW}$ power tiller for drawbar performance with three-bottom mouldboard plough and 5-tyne cultivator, revealed that use of $60 \mathrm{~kg}$ ballast weight could develop a maximum pull of $1333.75 \mathrm{~N}$ with cage wheels under field conditions [3]. In wet fields, with a hard pan at considerable depth, the utility of agricultural machines is limited due to their bogging down in the soil. Verma [4] revealed that cage wheel exerted 3 times more pull in comparison with tyres in flooded soil conditions. In agricultural operations, the effect of the vehicle on the soil is more important than the maximum traction that can be developed. A tractor that develops the desired pull at high efficiency may not be useful if it makes ruts in the soil so severe that subsequent cultural operations are adversely affected. Application of a drawbar load improves the performance of lighter tractors on wet soil because it increases the driving axle load by the effect of weight transfer [5]. Traction problems in the saturated paddy soils have a major limitation to the adaptation of agricultural mechanization in rice producing Asian countries. Sinkage of agricultural machinery has been the topic of intensive research in the past and will continue to be in the future. The main problem in mechanizing paddy cultivation is the development of a suitable traction device for operation in the saturated soils. Soft soils with low trafficability have resulted in excessive sinkage of agricultural machinery. Considerable time and energy are lost in attempting to cultivate in soft soils. Because of the extra time necessary to remove sunken machinery from the fields.

\section{Material and Method}

The experiments were conducted in the Indira Gandhi Krishi Vishwavidyalaya research farm Raipur in clay soil. Two replications were taken for testing each set of cage wheel in wet and puddle soil condition. The average values of soil properties are shown in (Table 1). Small power tiller of Greaves Ltd. of $4.85 \mathrm{~kW}$ engine power were used to test both cage wheels of $\mathrm{C}_{1}$ and $\mathrm{C}_{2}$ (Fig.1) attached with five tynes cultivator in wet and puddle soil to comparing the performance of power tiller in terms of tractive efficiency and drawbar pull. The field was prepared by cultivator and rotavator for creating a puddled soil conditions. Specification of both cage wheels for testing is given in Table 2. For evaluating performance of both cage wheel following points are taken.

\section{Effective Field Capacity}

It is the actual average rate of area covered by the implement. The total time required to complete the operation was recorded and effective field capacity was calculated as follows,

Actual field capacity $($ hah $)=\mathrm{A} / \mathrm{T}$

Where,

$$
\begin{aligned}
& \mathrm{A}=\text { actual area covered, ha. } \\
& \mathrm{T}=\text { total time required to cover an area, } \mathrm{hr} .
\end{aligned}
$$




\section{Field Efficiency}

This gives an indication of the time lost in the field and the failure to utilize the full working width of the machine. It is calculated as follows,

Field efficiency $(\%)=($ Effective field capacity $) /($ Theoretical field capacity $) \times 100$

\section{Fuel Consumption}

It was measured with fuel fill top-up method. Before operating, the tank of power tiller was filled completely with fuel and after the operation was performed, the fuel tank refilled up to same level. The total quantity of fuel needed to refill the fuel tank up to the same mark was recorded and total time was taken in test plot.

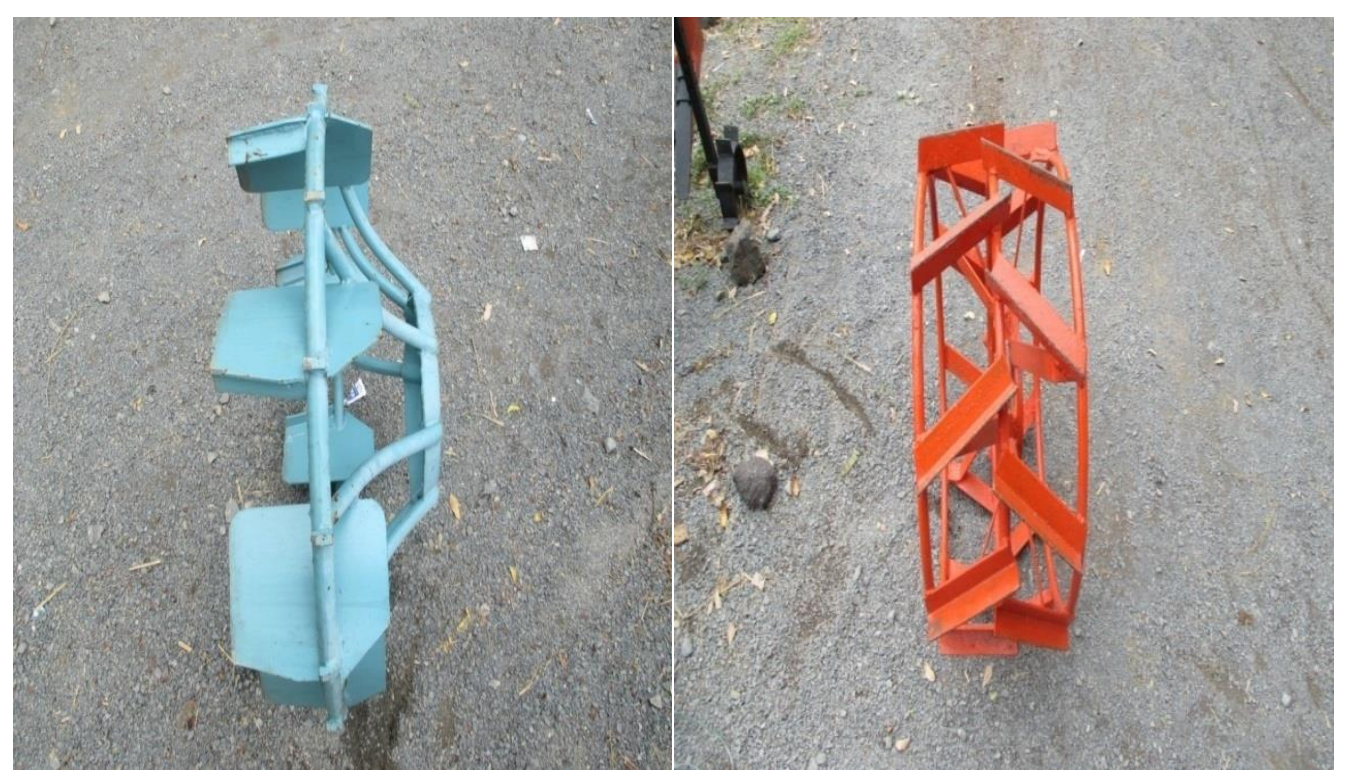

Fig. 1: Half width $C_{1}$ and angle type $C_{2}$ cage wheel.

\section{Measurement of Draft}

A loading car was used to measurement of draft of the power tiller. A commercially available proving ring type of load cell with strain gauges (Novatech, UK Model TR150) with a capacity of 0-4900 N, was used in the loading device for measurement of draft. The two ends of the load cell were mounted through articulated eye joints. The loads on the power tiller were varied by moisture content and were taken in load and no load conditions. The output of the load cell was connected to the digital indicator unit [6]. The indicator unit directly indicated the draft of the power tiller Fig 2. 


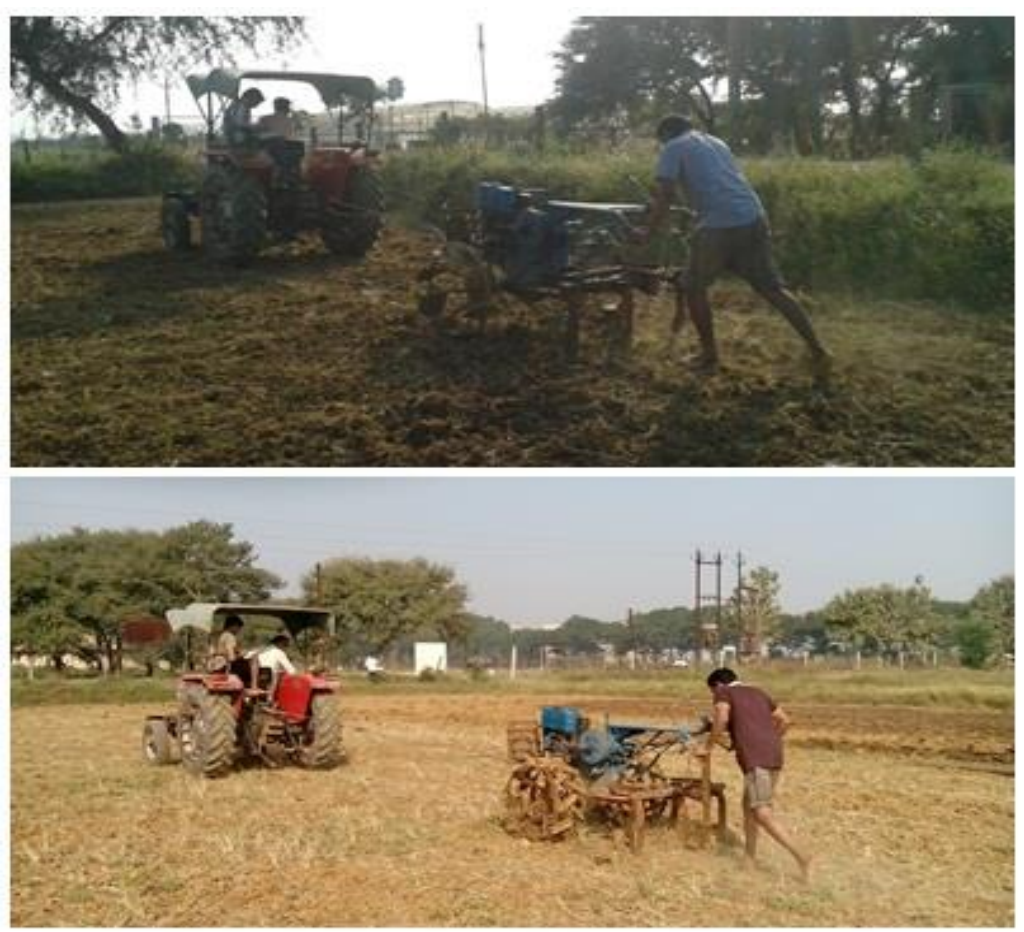

Fig. 2: Measurement of draft of both cage wheel $\mathrm{C}_{1}$ and $\mathrm{C}_{2}$ by load cell.

Measurement of Drawbar Power: For measuring drawbar power is calculated by the following formula.

$$
D p=\frac{P \times V}{1000}
$$

where, Dp is a drawbar power $(\mathrm{kW})$

$\mathrm{V}$ is the actual forward speed (with load) $(\mathrm{m} / \mathrm{s})$, and

$\mathrm{P}$ is the pull generated $(\mathrm{N})$.

\section{Tractive Efficiency (TE)}

Tractive efficiency is defined as output power / input power. It can also be expressed as the product of pull ratio and velocity ratio. From a power tiller drawbar power standpoint, tractive efficiency (TE) is the most important of the traction parameters. It measure efficiency, with which the traction device transmit torque, acting on the axle to the linear drawbar pull.

$$
\text { T. E. }=\frac{\text { Driving force }}{\text { Tractive Force }}=\frac{\text { Drawbar Power }}{\text { Axle Power }}
$$




$$
\text { Axle Power }=\frac{2 \text { лNT }}{60} \times \text { linear speed }
$$

\section{Wheel Slip}

The distance of the power tiller moves in a given number of revolutions of the drive wheel decreases when wheel slip. A simple method of determining the amount of wheel slip is to make a mark on the power tiller drive cage wheel with coloured tapes and the distance of power tiller covered at load and no load. Following formula are used to compute wheel slip-

$$
\text { Wheel slip, } \quad S=\frac{N 1-N 2}{N 1}
$$

where,

$$
\begin{aligned}
& \mathrm{N} 1=\text { speed at no load m/s } \\
& \mathrm{N} 2=\text { speed at load m/s }
\end{aligned}
$$

\section{Puddling Index}

Soil water suspension samples volume of $500 \mathrm{ml}$ were collected during puddling from different spots behind the puddling equipment with the help of $1.25 \mathrm{~cm}$ diameter steel pipe. The soil water suspension was allowed to settle for 48 hours and the volume of soil settled was recorded. Puddling index was determined by the following relationship [7].

$$
\text { Puddling index }(\mathrm{PI})=\frac{\mathrm{Vs}}{\mathrm{V}} \times 100
$$

where,

$$
\begin{aligned}
& \mathrm{Vs}=\text { Volume of settled soil, } \mathrm{ml} \\
& \mathrm{V}=\text { Total volume of the sample, } \mathrm{ml}
\end{aligned}
$$

\section{Soil Sticking}

It was measured with suitable scale on lug surface of cage wheel during operation in wet and puddle soil Fig 3. 


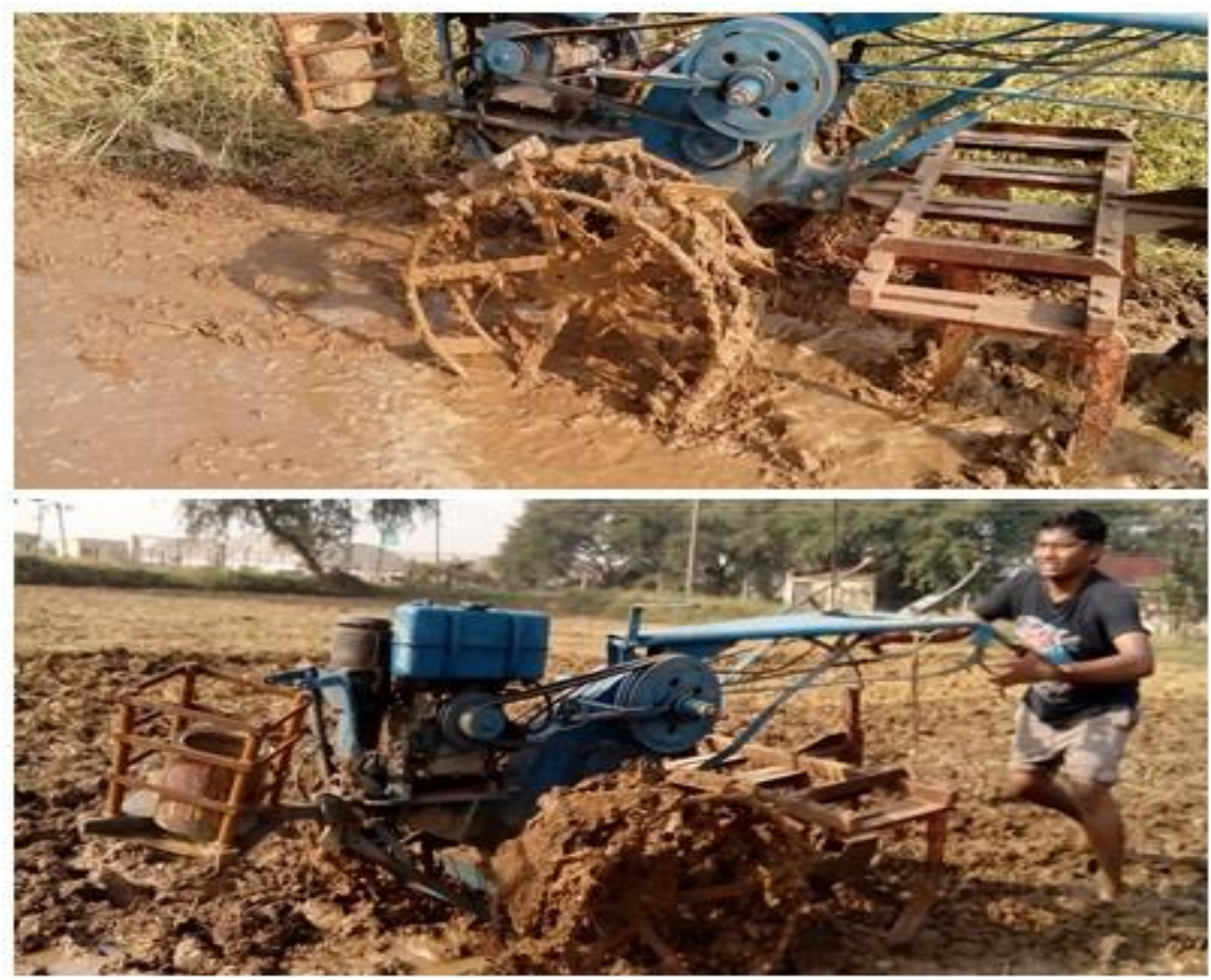

Fig. 3: Sticking of soil on lug surface in puddle and wet soil condition.

Table 1: Experimental setup and soil condition.

\begin{tabular}{|l|l|}
\hline rpm of cage wheel $\mathrm{C}_{1}$ & $17 \mathrm{rev} / \mathrm{min}$ \\
\hline Linear speed & $0.62 \mathrm{~m} / \mathrm{s}$ \\
\hline rpm of cage wheel $\mathrm{C}_{2}$ & $20 \mathrm{rev} / \mathrm{min}$ \\
\hline Linear speed & $0.87 \mathrm{~m} / \mathrm{s}$ \\
\hline Clay soil & $53 \%$ \\
\hline Silt & $32 \%$ \\
\hline Sand & $15 \%$ \\
\hline Soil Moisture & $47 \%$ \\
\hline Internal friction angle & $26.14^{\circ}$ \\
\hline
\end{tabular}


Table 2: Parameter of cage wheels

\begin{tabular}{|l|l|l|}
\hline S.N. & Angle type $\mathbf{C}_{\mathbf{1}}$ & Half width $\mathbf{C}_{\mathbf{2}}$ \\
\hline Wheel diameter & $600 \mathrm{~mm}$ & $700 \mathrm{~mm}$ \\
\hline Wheel width & $240 \mathrm{~mm}$ & $120 \mathrm{~mm}$ \\
\hline No of lug & 20 & 8 \\
\hline Lug width & $200 \mathrm{~mm}$ & $210 \mathrm{~mm}$ \\
\hline Lug length & $50 \mathrm{~mm}$ & $130 \mathrm{~mm}$ \\
\hline Lug angle & $30^{\circ}$ & $45^{\circ}$ \\
\hline Lug thickness & $5 \mathrm{~mm}$ & $4 \mathrm{~mm}$ \\
\hline Lug height & $50 \mathrm{~mm}$ & $30 \mathrm{~mm}$ \\
\hline
\end{tabular}

\section{Result and Discussion}

The experiment was carried out in IGKV Raipur farm in two replications, where cage wheel $\mathrm{C}_{1}$ and $\mathrm{C}_{2}$ were used to evaluate field performance and tractive performance in wet and puddle soil condition. Cage wheels were tested by power tiller attached with five tines of cultivator in the field were investigated for wheel slippage, effective field capacity, and fuel consumption, sinkage, sticking and puddling index. The obtained results are given in Table 3.

Table 3: Performance of Half width and Angle type cage wheel.

\begin{tabular}{|l|l|c|c|c|c|}
\hline \multirow{2}{*}{ S. No } & \multirow{2}{*}{ Operation } & \multicolumn{2}{|c|}{ Wet condition } & \multicolumn{2}{c|}{ Puddle condition } \\
\cline { 3 - 5 } & & $\mathbf{C}_{\mathbf{1}} \mathbf{7 3} \mathbf{~ c m}$ & $\mathbf{C}_{\mathbf{2}} \mathbf{6 8} \mathbf{~ c m}$ & $\mathbf{C}_{\mathbf{1}} \mathbf{7 3} \mathbf{~ c m}$ & $\mathbf{C}_{\mathbf{2}} \mathbf{6 8} \mathbf{~ c m}$ \\
\hline 1 & Time of operation (h/ha) & 16.66 & 14.49 & 13.88 & 11.90 \\
\hline 2 & $\begin{array}{l}\text { Effective width of } \\
\text { implement (mm) }\end{array}$ & 1500 & 1500 & 1500 & 1500 \\
\hline 3 & Field capacity (ha/h) & 0.06 & 0.069 & 0.072 & 0.084 \\
\hline 4 & Field efficiency \% & 72 & 86 & 68 & 77 \\
\hline 5 & Working speed & 1.04 & 1.22 & 1.33 & 1.58 \\
\hline 6 & Fuel consumption lit/ha & 15.36 & 13.62 & 11.57 & 09.83 \\
\hline 7 & Puddling index & - & - & 23.47 & 30.91 \\
\hline 8 & $\begin{array}{l}\text { Soil sticking in cage wheel } \\
\text { (cm) }\end{array}$ & 6.2 & 4.8 & 2.92 & 1.79 \\
\hline 9 & Sinkage (cm) & 9.12 & 7.29 & 8.56 & 6.31 \\
\hline 10 & wheel slip \% & 22.37 & 18.56 & 16.95 & 13.43 \\
\hline
\end{tabular}

From the Table 3 it was observed that field performance of angle type cage wheel $\mathrm{C}_{2}$ was highest than half width cage wheel $C_{1}$. Maximum time of operation required in wet lad operation in half width cage wheel of $16.66 \mathrm{~h}$ for per ha. 


\section{Effect of draft on tractive performance and drawbar power of the half width and angle type cage wheel in wet soil}

The maximum tractive efficiency with minimum wheel slip of the angle type cage wheel (lug size: $200 \times 50 \mathrm{~mm}^{2}, 30^{\circ}$ lug angle and 20 lugs on a wheel) in clay soils were relatively good as compared with the results obtained by half width cage wheel (lug size $210 \times 130 \mathrm{~mm}^{2}, 45^{\circ}$ lug angle and 8 lugs). Due to 20 lugs and $240 \mathrm{~mm}$ wheel width greater interaction of soil and wheel caused more tractive efficiency of angle type cage wheel $\mathrm{C}_{2}$ in wet land was maximum 66.96,62.60, and $60.82 \%$ at $18.56 \%$ wheel slip as compare $\mathrm{C}_{1}$ of attached $8 \mathrm{lugs}$ and wheel width $120 \mathrm{~mm}$ produce tractive efficiency with 63.41,59.32 and 56.26 at $22.37 \%$ slippage. From this study, it was also revealed that, half width cage wheel $\mathrm{C}_{1}$ of tractive and drawbar performance was poor as compare with angle type cage wheel $\mathrm{C}_{2}$.

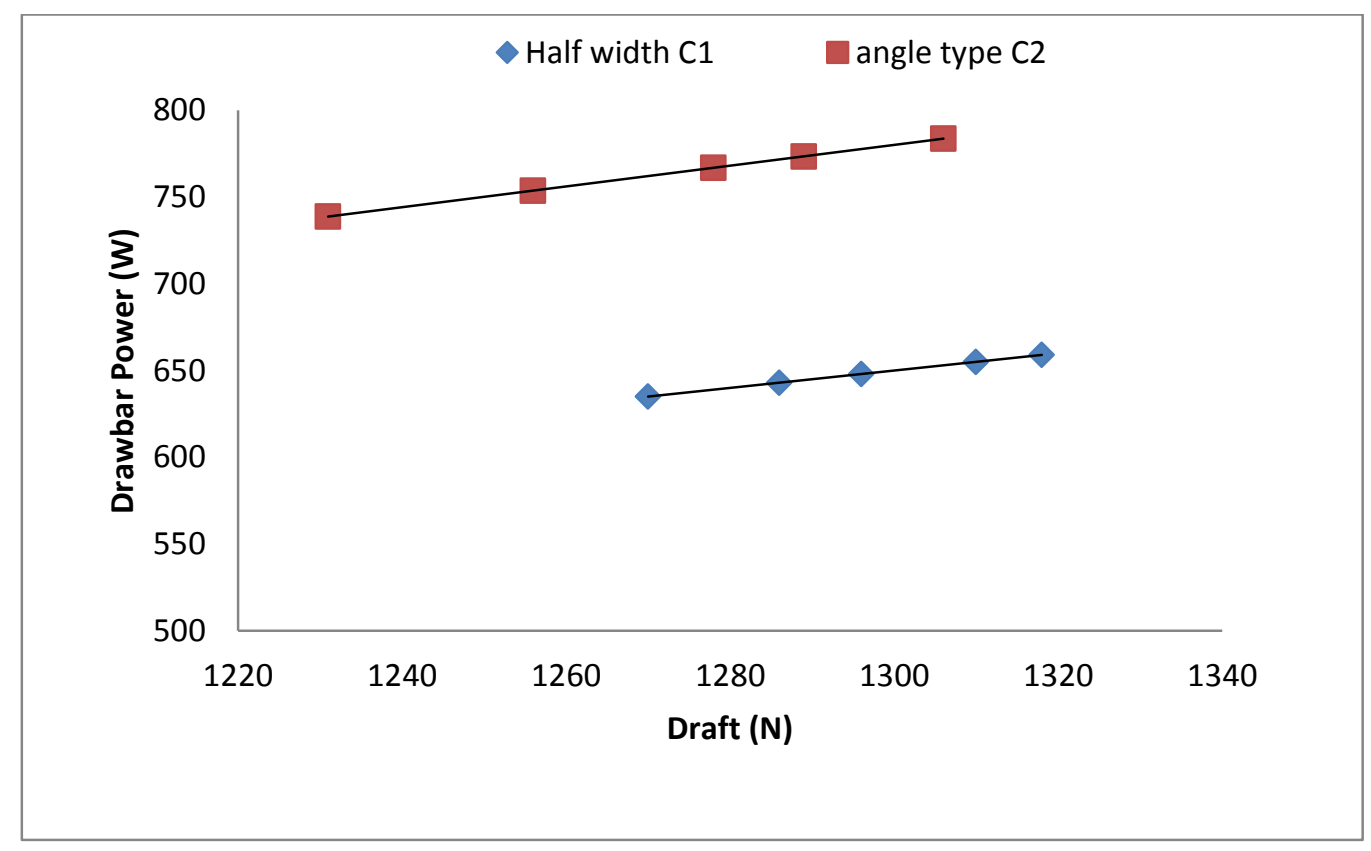

Fig. 4: Effect of draft on drawbar power on wet soil.

From the Fig.4 It was found that as draft and slippage increase the drawbar power also increases. Maximum drawbar power was $710.56 \mathrm{~W}$ for angle type cage wheel at $1225 \mathrm{~N}$ while minimum $635 \mathrm{~W}$ at $1270 \mathrm{~N}$ draft as given in Table 3. 


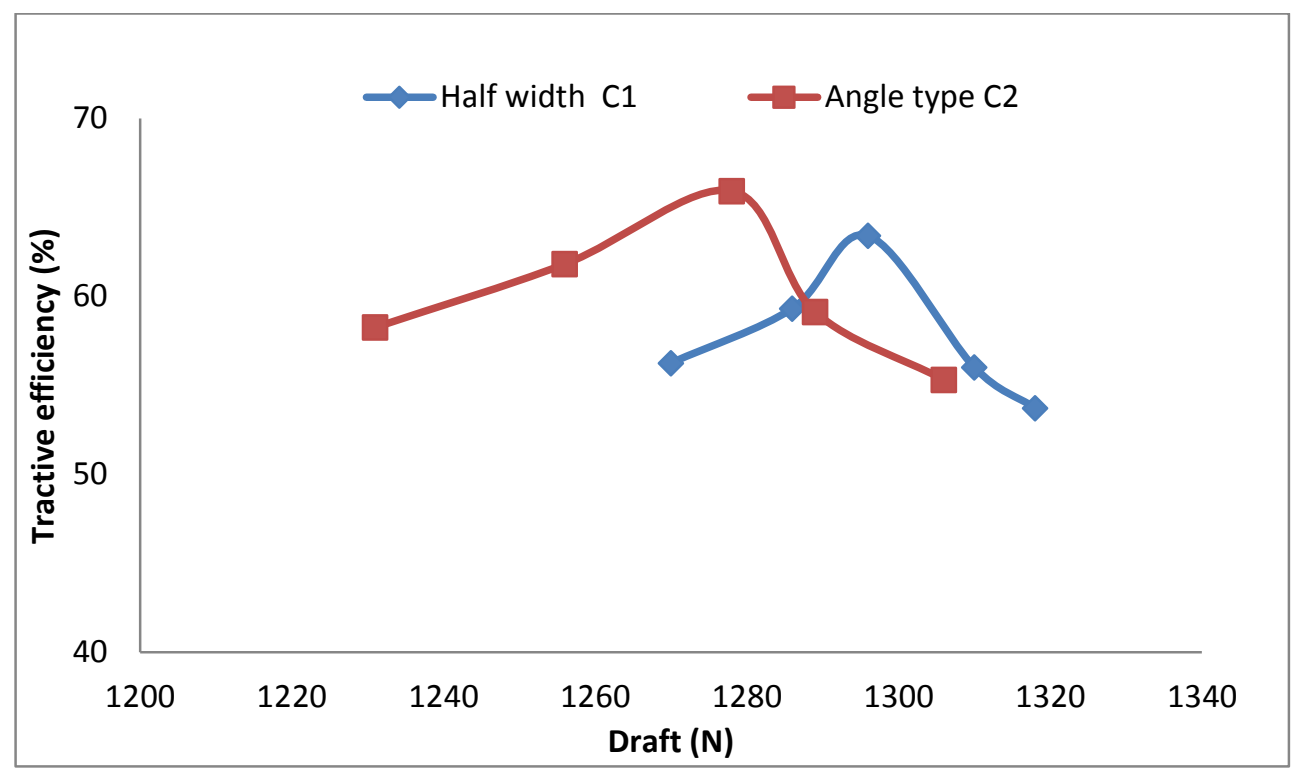

Fig 5: Effect of draft on tractive efficiency on wet soil.

From the Fig 5 it was resulted that as the draft increases tractive power increases till a maximum point than further decreases. The maximum tractive efficiency was observed $66.96 \%$ with draft $1188 \mathrm{~N}$ at 18.56 $\%$ slippage for angle type cage wheel $\mathrm{C}_{1}$. It was also revealed from the study that as draft increases, working speed reduced due to increase in sinkage and slippage. The maximum tractive efficiency 63.41 $\%$ for half width cage wheel $\mathrm{C}_{2}$ at $1296 \mathrm{~N}$ whereas minimum tractive efficiency was observed $53.74 \%$ at $1318 \mathrm{~N}$ draft (Table 3).

Table 3: Performance of cage wheel in wet soil.

\begin{tabular}{|c|c|c|c|c|c|c|}
\hline \multirow{2}{*}{ S.No } & \multicolumn{3}{|c|}{ Half width cage wheel C1 } & \multicolumn{3}{c|}{ Angle type cage wheel C2 } \\
\cline { 2 - 7 } & Draft & $\begin{array}{c}\text { Drawbar } \\
\text { power } \\
(\mathrm{N})\end{array}$ & $\begin{array}{c}\text { Tractive } \\
\text { efficiency } \\
(\%)\end{array}$ & $\begin{array}{c}\text { Draft } \\
(\mathrm{N})\end{array}$ & $\begin{array}{c}\text { Drawbar } \\
\text { power } \\
(\mathrm{W})\end{array}$ & $\begin{array}{c}\text { Tractive } \\
\text { efficiency (\%) }\end{array}$ \\
\hline 1 & 1270 & 635 & 56.26 & 1162 & 673.96 & 60.82 \\
\hline 2 & 1286 & 643 & 59.32 & 1176 & 682.08 & 62.60 \\
\hline 3 & 1296 & 648 & 63.41 & 1188 & 689.04 & 66.96 \\
\hline 4 & 1310 & 655 & 56.02 & 1207 & 700.06 & 58.31 \\
\hline 5 & 1318 & 659 & 53.74 & 1225 & 710.56 & 55.44 \\
\hline
\end{tabular}


Table 4: Performance of cage wheel in puddle soil.

\begin{tabular}{|c|c|c|c|c|c|c|}
\hline \multirow{2}{*}{ S.No } & \multicolumn{3}{|c|}{ Half width cage wheel $\mathrm{C}_{1}$} & \multicolumn{3}{c|}{ Angle type cage wheel $\mathrm{C}_{2}$} \\
\cline { 2 - 7 } & Draft & $\begin{array}{c}\text { Drawbar } \\
\text { power } \\
(\mathrm{N})\end{array}$ & $\begin{array}{c}\text { Tractive } \\
\text { efficiency } \\
(\%)\end{array}$ & $\begin{array}{c}\text { Draft } \\
(\mathrm{N})\end{array}$ & $\begin{array}{c}\text { Drawbar } \\
\text { power } \\
(\mathrm{W})\end{array}$ & $\begin{array}{c}\text { Tractive } \\
\text { efficiency } \\
(\%)\end{array}$ \\
\hline 1 & 1130 & 565 & 62.12 & 987 & 651.42 & 65.76 \\
\hline 2 & 1148 & 574 & 64.53 & 996 & 657.36 & 68.59 \\
\hline 3 & 1166 & 583 & 69.86 & 1011 & 667.26 & 72.91 \\
\hline 4 & 1181 & 590.5 & 61.29 & 1024 & 675.84 & 63.33 \\
\hline 5 & 1192 & 596 & 54.17 & 1039 & 664.96 & 60.73 \\
\hline
\end{tabular}

\section{Effect of draft on tractive efficiency and drawbar power in puddle soil}

The increase in soil moisture content caused a decrease in the peak values of pull and lift forces. The peak values of pull and lift forces at $24 \%$ soil moisture content were much higher than those at 30,35 and $44 \%$ soil moisture contents [8] from study it was found that increasing moisture content in field drawbar pull decrease but drawbar power efficiency increases because greater interaction of soil and wheel. As increasing of draft up to $1166 \mathrm{~N}$ in cage wheel tractive efficiency increases maximum at $69.86 \%$ and then further decreases but draft increases continuous increases to $1192 \mathrm{~N}$ Fig (6\&7). Minimum tractive efficiency obtained $29.24 \%$ at 136 N. Keuther [9] concluded in soil bin that the continuous use of machines in flooded field conditions increased the hard pan depth and bogging problems become so serious from the fifth crop season. Salokhe [10] studied soil wedge formation on a single lug by conducting experiments in a laboratory soil bin in Bangkok clay soil.

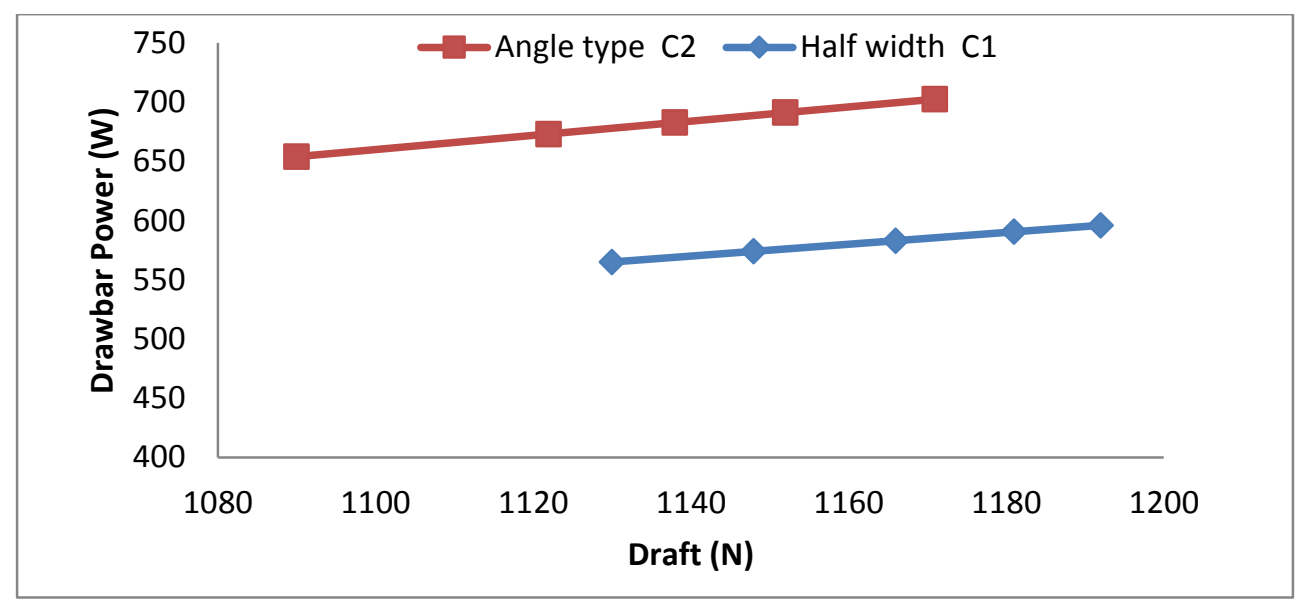

Fig. 6: Effect of draft on drawbar power in puddle soil. 
Maximum drawbar $675.84 \mathrm{~W}$ was obtained at $1024 \mathrm{~N}$ draft where tractive efficiency was $63.33 \%$.maximum tractive efficiency was $72.91 \%$ at $1011 \mathrm{~N}$ for angle type cage wheel $\mathrm{C}_{2}$. Increasing draft, tractive efficiency increases, but with the increase draft it again falls, Fig 7.

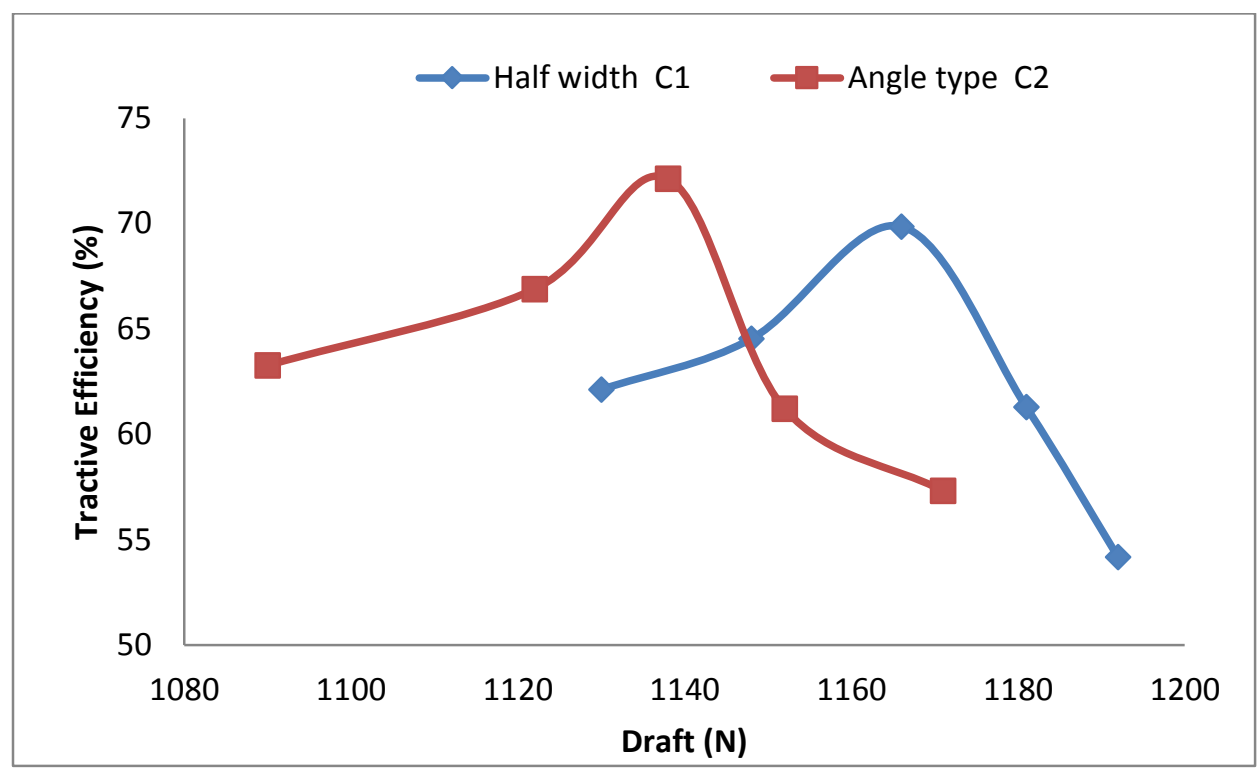

Fig. 7: Effect of draft on tractive efficiency on puddle soil.

\section{Conclusions}

It was concluded that as increasing the pull of power tiller drawbar power increases in both cage wheel and tractive efficiency increases at point than further decreases. This study showed that increasing the moisture strongly affects the wedge formation over the lug plates of the cage wheel operated on clay soil.

\section{References}

[1] M.S. Abubakar, D. Ahmad, J. Othman, and S. Sulaiman, Research Journal of Agriculture and Biological Sciences, 5(4) (2009) 489-497.

[2] S. A. A. Alvi and A. C. Pandya, The Harvester, IIT, Kharagpur, India, 10 (1) (1968) 51-61.

[3] J. S. Panwar, S. K. Tondan and N. P. S. Sirohi, Performance evaluation of power machine systems for tillage and traction, Annual Report, Division of Agricultural Engineering, Indian Agricultural Research Institute, New Delhi, India, 1984.

[4] S. Verma, Development and testing of refractive lugged cage wheels, Asian Institute of Technology, M. Eng Thesis no. AE-84-12, 1984 (Unpublished). 
[5] M. J. Baloch, B.A. Mirani and S. Bukhari, Agricultural Mechanization in Asia, Africa and Latin America, 22(4) (1991) 21-24.

[6] Suresh Narang and A. C. Varshney, Journal of Terramechanics, (32) (2) (1995) 91-97.

[7] B. Baboo, Effect of lug angle of cage wheel on traction and puddling performance of dual wheels, M. Tech. Diss., Dept. of Farm Machinery and Power Engineering, G. B. Pant Univ. of Agriculture and Technology. Pantnagar, India, 1976.

[8] Wawan Hermawan, Journal of Terramechanics, (33) (2) (1996) 91-101.

[9] D.O. Keuther, Soil compaction and wetland rice tillage system, Am Soc. Agric. Engrs. Paper no. 77-1021, 1977.

[10] V. M. Salokhe and D.Gee-Clough J. Agric. Engg Res., 38 (1987) 113-125. 